\title{
PEDAGOGICAL SUPPORT OF COMPULSORY MEASURES OF EDUCATIONAL INFLUENCE ON JUVENILE DELINQUENTS
}

\author{
Tatyana Kazakova \\ Academy of the Federal Penal Service of Russia, Russian Federation \\ Irina Vassilyeva \\ Academy of the Federal Penal Service of Russia, Russian Federation \\ Olga Varlamova \\ Academy of the Federal Penal Service of Russia, Russian Federation \\ Yuri Vorobyov \\ Academy of the Federal Penal Service of Russia, Russian Federation \\ Tatyana Dazmarova \\ Academy of the Federal Penal Service of Russia, Russian Federation \\ Vladimir Zakopyrin \\ Academy of the Federal Penal Service of Russia, Russian Federation
}

\begin{abstract}
The article presents the results of an empirical study. The aim of the study is to increase the effectiveness of compulsory measures for juvenile delinquents through the development and implementation of the pedagogical support system of these measures.

The urgency of the research is determined by the lack of the scientific and methodological support for the practical implementation of compulsory measures of educational influence on juvenile delinquents; by the low level of the psychological and pedagogical readiness of the subjects of the pedagogical interaction; insufficiency of the pedagogical support as the most important condition of these measures effectiveness. Research methods are pedagogical analysis and synthesis, induction and deduction, comparison and generalization of research results, questionnaires, interviews, individual and group conversations, observation, generalization of independent characteristics, statistical methods of information processing.

According to the research aim the system of the pedagogical support of compulsory measures of educational influence on juvenile offenders was developed and tested. It includes organizational and substantial, technological and staff resource components and their interaction, the main directions and ways for increasing of the pedagogical training level of the subjects of the pedagogical interaction. The results of the investigation proved the effectiveness of the pedagogical support system of compulsory measures for juvenile delinquents.
\end{abstract}

Keywords: components of the system; compulsory measures; educational influence; juvenile delinquents; pedagogical support; punishment; system. 


\section{Introduction}

Young people are the priority value, the hope of any society, because the well-being and wealth of any nation depends on them. That is why the problem of juvenile delinquency is perceived so sharply as an extreme form of asocial behaviour. The dynamics of crimes committed by minors is characterized by an upward trend. This stimulates the search for effective ways for preventing juvenile delinquency and rehabilitation of minors. The analysis of statistical data shows that the majority of minors $(81.5 \%)$ sentenced to compulsory measures of educational influence have shown promise to rehabilitation, since during the next year they did not commit any offenses. So, the problem of further optimization of these measures remains urgent. Our research showed that the educational potential of these measures is not used sufficiently. Their proportion in correctional practice in recent years is about $16 \%$. So, in 2017 courts sentenced 1096 juveniles to compulsory measures of educational influence, in 2018 - 1110, in 2019 - 1125. (Official website of the Supreme Court of the Russian Federation, 2015-2019). At the same time international rules, the Development Concept of the Penal System of the RF until 2025 and judiciary practice in relation to minors suggest an expansion of the scope of punishments and measures alternative to imprisonment. The effectiveness of compulsory measures of educational influence depends on their appropriate pedagogical support. Thus, the necessity of the development of the system of the pedagogical support of compulsory measures of educational influence on juvenile offenders is obviously urgent.

The object of the research is the process of practical implementation of compulsory measures of educational influence on juvenile offenders.

The subject of the research is the essence and content of pedagogical support for the process of practical implementation of compulsory measures of educational influence on juvenile delinquents.

The aim of the investigation is theoretical justification and development of the system of the pedagogical support of compulsory measures of educational influence on juveniles which optimizes their effectiveness as well as testing of its effectiveness in the process of rehabilitation of juvenile delinquents.

The main theoretical methods are pedagogical analysis and synthesis, induction and deduction, comparison and generalization of the research results. The empirical base of the study is represented by a pilot study, questioning, interviewing, individual and group conversations, observation, comprehensive and formative assessment, expert assessment, generalization of independent characteristics and statistical methods of information processing. 


\section{The Theoretical Basis of the Study}

The theoretical basis of the research includes a system of scientific theories, approaches and methods. Some of the theoretical foundations of our research we have determined in our previous investigations (Vassilyeva, et al., 2019). These are ideas about the social conditions of behaviour, communication and human activity, its subjectivity in interaction with social and natural environment; ideas about professional activity as a social function of a person; the theory of integrity and interdependence of social and pedagogical phenomena in the process of individual educating (Vygotskij, 2010; Ushinskij, 1953); the states of the theory and methodology of education as a holistic personality development process in a specially organized educational system (Makarenko, 1984; Suhomlinskij, 1975); the theory of socio-psychological and socio-pedagogical features of juvenile delinquents personality (Beljaeva, 1995); personal and activity approaches to the selection of content and means of educational influence on juvenile delinquents (Belicheva, 2006; Gurov, 2004; Kosikovskij, 2006); theoretical foundations of the formation of specialists readiness for professional activity (Pozdnjakov, 2002); methods of the professional training optimization in corrections (Belicheva, 2006; Unarova, 2000).

The aim of the research was achieved by the complex of interrelated and complementary scientific methods. The main theoretical methods are pedagogical analysis and synthesis, induction and deduction, comparison and generalization of the research results. The empirical base of the study is represented by a pilot study, questioning, interviewing, individual and group conversations, observation, comprehensive and formative assessment, expert assessment, generalization of independent characteristics and statistical methods of information processing.

\section{Research Results}

The application of compulsory measures of educational influence on juvenile convicts is a state task of social significance. Their use was previously one of the priority directions of the juvenile delinquency prevention and rehabilitation of minors, but without pedagogical support for their implementtation these measures could not become an effective means of correction. The success of the use of compulsory measures of educational influence is determined by the systematical scientifically grounded pedagogical support of the main subjects of juvenile delinquents correction which was actually absent or was unsystematical. Our research proved that with appropriate pedagogical 
support the effectiveness of the correction and resocialization of juvenile offenders increases.

The analysis of different approaches to the definition of the aims, essence and characteristics of compulsory measures of educational influence on juvenile offenders lets determine them as a system of penal measures applied by courts to juvenile offenders who have committed minor offenses and aimed at their correction, prevention of new crimes, individualization of the pedagogical influence carried out under conditions of state compulsion (Kazakova, 2015). It should be noted that in previous investigations the problem of compulsory measures implementation for juvenile delinquents was considered only from the juridical point of view (Beljaeva, 1995; Ermakova, 2018; Kanokova, 2015; Pozdnjakov, 2002). This research is an attempt to solve this problem in the framework of penitentiary pedagogy and juridical psychology. From this point of view this system is based on the principles of a humanistic orientation, pedagogical, preventive viability and individualization of the pedagogical influence. Its effectiveness is ensured by the combination of legal restrictions and requirements with educational, corrective and rehabilitative measures, by maximum use of the positive influence of the microenvironment, education, communication which contribute to the decriminalization of minors behaviour.

Each of these measures differs not only in the degree of penal compulsion, creating external conditions for juveniles behaviour regulation and positive experience formation, but also in methods of educational (corrective, preventive, rehabilitative) influence that stimulate intrapersonal changes, development and self-education. The pedagogical support of main subjects of pedagogical interaction by realization of compulsory measures includes the process of developing, substantiating and testing of methods, means and technologies for juveniles' correction, as well as practical training of subjects for successful work at the personal and competence level.

Pedagogical support of compulsory measures of educational influence on juveniles is a complex of scientifically grounded pedagogical technologies aimed at creation of a system of effective work with this category of minors, including the aim and objectives, essence and content, pedagogical conditions for the implementation of these measures (Kazakova, 2014). It is characterized by specifics determined by the circumstances in which the process of their practical implementation is organized (maintenance of the habitual microenvironment, legal restrictions, pedagogical regime); by the peculiarities of subjects of pedagogical interaction. These are on the one hand juveniles offenders released from criminal liability and sentenced to compulsory measures of educational influence, but having a complex of social, legal, psychological, pedagogical problems including personality development deformations and on the other hand the staff of the penal inspections, parents of minors, other family 
members or persons in loco parentis, representatives of the commissions on juvenile affairs and their rights protection, state, public, educational bodies and others (Kazakova, 2014).

The analysis of the penal practice shows that the pedagogical facilities of compulsory measures of educational influence on juvenile offenders are underestimated. The main reasons for their rare use are insufficient pedagogical orientation, the lack of modern technologies for specific activities, the lack of the interaction between the main subjects of the implementation of these measures and the lack of pedagogical support in general. Employees of the penal inspections of the territorial bodies of the Ministry of Internal Affairs of Russia, families of juvenile delinquents and other subjects of the practical implementation of these measures have difficulties in educational work with problem juveniles because they are practically not ready for this pedagogical activity. They do not possess the psychological and pedagogical knowledge, skills and abilities, the appropriate scientific and methodical instruments for the implementation of these measures. Their activities are poorly organized and not provided with appropriate pedagogical support.

The analysis of the current state of the problem allowed to identify some disadvantages in the investigated measures applying, to determine their causes and to develop a system of pedagogical support for the practical implementation of compulsory measures of educational influence on juvenile delinquents.

The research was carried out in three stages: the theoretical one, including the determination of the object, the subject and the aim of the research, the study of scientific sources on the problem, the definition of its theoretical foundations and the theoretical development of the pedagogical support system; the experimental one, consisting of comprehensive and formative experiments; and the final one, including processing, generalizing of the data, formulation of the conclusions, comparing them with the hypothesis and theoretical foundations of the analyzed problem.

The experimental work was aimed at development and testing of a system of pedagogical support for compulsory measures of educational influence, as well as at identifying and estimating of social and pedagogical conditions for improving of their practical implementation. The developed and experimentally tested system of pedagogical support for the practical implementation of compulsory measures of educational influence on juvenile delinquents includes organizational and substantial, technological and staff resource components and their interaction, the main directions and ways for increasing of the pedagogical training level of the subjects of the pedagogical interaction.

Developing the criteria and indicators for assessing the pedagogical potential of the subjects of pedagogical interaction, we operated on the premise that they can be determined on the following basis: 1) legal, psychological and pedagogical competence that means deep knowledge and readiness of the penal 
inspections employees and other subjects of practical implementation of compulsory measures of educational influence; 2) humanistic and social orientation of constantly changing educational activity in the "person - person" system by which external influence of pedagogical support stimulate internal activity of subjects of pedagogical interaction by using of pedagogical potential and self-correction of minors; 3) diagnostic value (the criteria must allow a comprehensive and objective assessment of the result of the activity of employees, relatives and other subjects of the practical implementation of educational compulsory measures to convicted minors). This methodological basis allowed to identify and to substantiate the criteria and indicators for the pedagogical potential assessing of the subjects of the implementation of compulsory measures of educational influence on juvenile offenders. In the context of this study the criterion characterizes the pedagogical potential of the subjects of the implementation of compulsory measures, the more complete development of which should be ensured by pedagogical support. The content of the criterion is represented by indicators which allow to identify the degree of intensity of the corresponding skills and abilities of the penal inspections employees and juveniles' parents, and on the basis of their comprehensive assessment to make conclusions about the level of their pedagogical potential.

So, the criteria for assessing the pedagogical potential of the subjects of implementation of compulsory measures of educational influence on juvenile delinquents are: 1) cognitive which reflects socio-pedagogical knowledge and pedagogical culture necessary for carrying out educational work with minors, their parents and other subjects of pedagogical interaction; 2) operational and practical characterizing the practical readiness of juvenile affairs officers, parents and other subjects of pedagogical interaction to apply effective technologies of pedagogical activities; 3) need and motivational which characterizes the social maturity of juvenile affairs officers, parents and other subjects of pedagogical interaction and is manifested in the understanding of the need for pedagogical development, psychological and organizational readiness to master social, personal and professional knowledge, pedagogical skills and culture for the successful implementation of compulsory measures of educational influence on juvenile delinquents.

Each of these criteria includes a number of indicators. So, the cognitive criterion for assessing the pedagogical potential of the subjects of juvenile delinquents reformation includes the following indicators: depth and consistency of social and pedagogical knowledge; initiative in the search for innovative approaches to education; the choice of strategy in interaction with other subjects involved in the implementation of compulsory measures of educational influence on juvenile delinquents. The indicators of the operational and practical component of the pedagogical potential of the main subjects of the activity are 
awareness of modern pedagogical technologies (positive experience) for reforming adolescents and the skills to apply them in practice, as well as systematic and active work on the implementation of compulsory educational measures. The need and motivational criterion suggests such evaluative indicators as understanding the need for, concern of subjects of pedagogical interaction in educational activities for juvenile delinquents and motivation for appropriate behaviour in the process of interaction with organizations and persons participating in the juvenile delinquents reformation.

According to the manifestation degree of each indicator and their certain combination three levels of the development of the pedagogical potential of the subjects of educational interaction (high, medium, and low) were identified. Such methods as questioning, interviewing, individual and group conversations, observation allowed to define the level of the pedagogical potential of the subjects involved in the realization of the system of pedagogical support of compulsory measures of educational influence (Kazakova, 2010).

The developed and theoretically justified system of pedagogical support of compulsory measures of educational influence on juvenile delinquents, including organizational and substantial, technological and staff resource components, as well as diagnostic instruments (the distinguished criteria, indicators and levels of development of the pedagogical potential of the subjects of educational interaction) was tested during the empirical work.

The experimental work was conducted among the main subjects of interaction: employees of units (offices) for juvenile affairs and parents (legal representatives) of adolescents. The initial diagnostics of the level of the pedagogical potential of the subjects of educational interaction was carried out beforehand. The results of the experiment are represented in Table 1.

Table 1 Dynamics of the Level of Pedagogical Potential of the Employees of the Units (offices) for Juvenile Affairs and Parents of Juvenile Delinquents

\begin{tabular}{|c|c|c|c|c|c|c|}
\hline \multirow{2}{*}{$\begin{array}{c}\text { Subjects of } \\
\text { educational } \\
\text { interaction }\end{array}$} & \multicolumn{5}{|c|}{$\begin{array}{c}\text { Level of pedagogical potential of the employees } \\
\text { of the units for juvenile affairs (\%) }\end{array}$} \\
\cline { 2 - 7 } & $\begin{array}{c}\text { Before } \\
\text { the } \\
\text { formative } \\
\text { experiment }\end{array}$ & $\begin{array}{c}\text { After the } \\
\text { formative } \\
\text { experiment }\end{array}$ & $\begin{array}{c}\text { Before the } \\
\text { formative } \\
\text { experiment }\end{array}$ & $\begin{array}{c}\text { After the } \\
\text { formative } \\
\text { experiment }\end{array}$ & $\begin{array}{c}\text { Before the } \\
\text { formative } \\
\text { experiment }\end{array}$ & $\begin{array}{c}\text { After the } \\
\text { formative } \\
\text { experiment }\end{array}$ \\
\hline 1 & 2 & 3 & 4 & 5 & 6 & 7 \\
\hline $\begin{array}{c}\text { Employees of the } \\
\text { units (offices) for } \\
\text { juvenile affairs }\end{array}$ & 20.0 & 23.0 & 34.0 & 35.0 & 46.0 & 42.0 \\
\hline $\begin{array}{c}\text { Parents of juvenile } \\
\text { delinquents }\end{array}$ & 19.0 & 26.3 & 54.0 & 60.5 & 27.0 & 13.2 \\
\hline
\end{tabular}


The analysis of the experimental data (Table 1) showed that after the summative experiment the low level dominated among almost half of the officers (46.0\%), and the high level of pedagogical potential was less common (20.0\%). They experience greater difficulties in activities that correspond to the cognitive criterion for assessing the pedagogical potential (lack of psychological and pedagogical knowledge) and the operational and practical criterion (lack of competencies in certain types of professional activity and its organization). It determined the necessity of implementation of the system of pedagogical support of compulsory measures of educational influence in order to increase the pedagogical potential of the subjects of educational interaction.

Not only juvenile affairs officers but also parents or legal representatives of juvenile offenders (or those in loco parentis) took part in the experiments. The data of the research indicated that before the formative experiment the subjects of pedagogical interaction demonstrated a low level of their pedagogical competence, pedagogical culture, and, consequently, ineffective activities and unproductive impact on convicted adolescents. More than half of them (54.0\%) had an average level of pedagogical potential development. More than a quarter (27.0 \%) showed a low level and only $19.0 \%$ had a high level of preparedness to participate in reforming the behavior of their fosterlings. Although these figures were slightly better than those describing juvenile affairs officers, the scientific forecast about the degree of their influence on the success of the reforming process was disappointing. Therefore, the need for pedagogical support for their participation in organizing of the activities for correcting previous mistakes in the upbringing of children was obvious.

The basis of the formative experiment was a set of training activities which made it possible to carry out a step-by-step improvement of the pedagogical potential of juvenile affairs officers and juveniles' parents. For this purpose differentiated programs were developed and implemented to increase the effectiveness of pedagogical support of compulsory measures of educational influence on juvenile delinquents for employees of the offices for juvenile affairs and parents of adolescents.

The experimental work aimed at increase of the level of the pedagogical potential of the subjects of educational interaction was carried out in two main directions: theoretical and practical training. Theoretical training was aimed mainly at increasing the least developed levels of cognitive and operational and practical components of the pedagogical potential of juvenile affairs officers: special psychological, pedagogical theoretical and methodological knowledge, practical skills and abilities to carry out educational and preventive work with juvenile offenders to whom compulsory educational measures are applied. Its results are manifested in the systemic ability to think pedagogically, the presence of analytical, prognostic, projective and reflective competences. The 
development of these competencies led to raising of the level of professional self-awareness, culture of behaviour, moral, psychological and social stability which help to understand the social role better and to develop the necessary professional attitude to minors, the ability to suppress one's own antipathy and work out an "optimistic hypothesis" approach.

Practical training was aimed at the formation of organizational and communicative skills of those who implement compulsory measures of educational influence. For this purpose the following instruments were developed and implemented: a special 76-hour training course "Pedagogical support of compulsory measures of educational influence on juvenile delinquents", including 26 hours of lectures, 28 hours of tutorials, and 22 hours of independent learning; a set of methodical recommendations for organizing personalized rehabilitation services for juvenile offenders; a set of methodical recommendations for increasing the pedagogical potential of the delinquent's family members; the exemplary topics of lectures and conversations for parents; a set of recommendations for holding individual conversations with minors to whom compulsory educational measures are applied (Kazakova, Kuznecov 2020).

The data obtained after the completion of the forming experiment testifies to the positive dynamics of the level of development of the pedagogical potential of the employees of the offices for juvenile affairs. Thus, the number of officers who had high and average level of pedagogical potential has increased (by 3\% and $2 \%$ respectively). At the same time there was a decrease (by $4 \%$ ) in their total number who had a low level of pedagogical potential. The data obtained convincingly testify to the positive results of the experimental work carried out. They once again confirm the effectiveness of the developed system of pedagogical support for the practical implementation of compulsory measures of educational influence on juvenile delinquents.

After the completion of the formative experiment parents whose children were registered in the offices for juvenile affairs demonstrated a tendency to growth of the pedagogical potential. The results obtained convincingly proved the considerable influence of pedagogical support on the level of the pedagogical potential of parents. In the experimental group there were positive quantitative and qualitative changes: the number of parents who had a low level of potential decreased significantly (by $13 \%$ ). Accordingly, the number of the subjects having high and average levels of development of their pedagogical potential noticeably increased after the formative experiment (by $8 \%$ and $4 \%$ respectively). The implementation of the system of pedagogical support of compulsory measures of educational influence on juvenile delinquents, its principles, methods, assessment criteria and indicators during the summative and formative experiments led to the optimization of the pedagogical orientation 
of juvenile affairs officers professional activity and the statistically reliable increase of pedagogical potential level and the culture of the delinquents' parents.

\section{Conclusions}

Thus, the research results proved the effectiveness of the developed system of the pedagogical support of compulsory measures of educational influence on juvenile delinquents, the goal of the investigation was achieved. Battle-testing of the developed system of pedagogical support of compulsory measures of educational influence on delinquent adolescents including organizational, technological and personnel-resource components, a complex of didactic means, methods and technologies for the development of the pedagogical potential of the subjects of the pedagogical interaction allowed to analyze its influence on the dynamics of the level of the pedagogical potential of the subjects of the implementation of compulsory measures; to assess its impact on the rehabilitation of minor offenders; to join the pedagogical efforts of juvenile affairs officers and parents of adolescents. The proposed system has not only theoretical, but also particular practical significance since it is directly related to the practice of juvenile affairs offices responsible for pedagogical work with minors in accordance with their pedagogical and psychological specifics. The study allowed to compensate for the insufficient development of both theoretical and practical aspects of the socially significant problem of implementing compulsory measures of educational influence on juvenile offenders, as well as to distinguish directions for its further investigation. These are the organization of a system of training, retraining and advanced training of specialists, social teachers, psychologists, social workers for the implementation of educational activities with juvenile offenders; organization of compulsory training on preventive and pedagogical issues for adolescents' parents or their legal representatives; application of proper psychological and pedagogical rehabilitation technologies for minors to whom compulsory measures of educational influence are applied and improvement of their implementation practice.

\section{References}

Belicheva, S. (2006). Social'naja podderzhka deteji semej gruppy riska. Mezhvedomstvennyj podhod.Moskva: Social'noezdorov'e.

Beljaeva, L. (1995). Stanovlenie i razvitie ispravitel'nyh zavedenij dlja nesovershennoletnih pravonarushitelej v Rossii (seredina XIX - nachalo XX v.).Moskva.

DOI: https://doi.org/10.17223/23088451/12/5 
Ermakova, O. (2018). Otdel'nye voprosy zakonodatel'no jreglamentacii prinuditel'nyh mer vospitatel'nogo vozdejstviya. Ugolovnayay usticiya, 12, 24-27.

Gurov, D. (2004). Pedagogicheskie aspekty profilaktiki pravonarushenij sredi nesovershennoletnih $v$ sisteme raboty OVD. Stavropol'.

Kanokova, L. (2015). Prinuditel'nye mery vospitatel'nogo vozdejstviya, primenyaemye k nesovershennoletnim. Teoriya i praktika obshchestvennogo razvitiya, 16, 121-124.

Kazakova, T. (2010). Model' pedagogicheskogo obespechenija prinuditel'nyh mer vospitatel'nogo vozdejstvija na nesovershennoletnih osuzhdennyh. Vestnik SanktPeterburgskogo universiteta MVD Rossii, 2 (46), 71-76.

Kazakova, T. (2014). Prinuditel'nye mery vospitatel'nogo vozdejstvija kak al'ternativa ugolovnomu nakazaniju. Vedomosti ugolovno-ispolnitel'noj sistemy, 2 (46), 71-76.

Kazakova, T. (2015). Ponjatie i specifika pedagogicheskogo obespechenija prinuditel'nyh mer vospitatel'nogo vozdejstvija na nesovershennoletnih pravonarushitelej. Vestnik SanktPeterburgskogo universiteta MVD Rossii. 4 (68), 195-199.

Kazakova, T., Kuznecov, M. (2020). Individual'naja vospitatel'naja rabota s podrostkamidelinkventami. In Nagornova, A. (Ed.), Obuchenie i vospitanie detej i podrostkov: ot teorii k praktike. Ul'janovsk. 253-267.

Kosikovskij A. (2006). Pedagogicheskaja napravlennost' profilakticheskoj dejatel'nosti uchastkovyh upolnomochennyh. Moskva.

Makarenko, A. (1984). Pedagogicheskie sochinenija. Moskva: Prosveshhenie.

Pozdnjakov, V. (2002). Juvenal'nyj vopros V penitenciarnoj sisteme Rossii. Nesovershennoletnie $v$ ugolovno-ispolnitel'noj sisteme Rossii: problem ispolnenija nakazanij, social'noj adaptacii $i$ ih sovershenstvovanija. Moskva: Centr sodejstvija pravosudiju pri fonde INDEM.

Suhomlinskij, V. (1975). O vospitanii. Moskva: Polit. Lit.

Supreme Court of the Russian Federation. (2015-2019). Note on the results of summarizing of the judicial practice of criminal cases consideration related to the release of minors from criminal liability and punishment. Retrieved from: http://www.gks.ru/wps/ wcm/connect/rosstat_main/rosstat/ru/statistics/population/infraction

Unarova, L. (2000). Social'no-pedagogicheskaja dejatel'nost' sotrudnikov organov vnutrennih del po profilaktike deviantnosti nesovershennoletnih. Jakutsk.

Ushinskij, K. (1953). Izbrannye pedagogicheskie sochinenija. Moskva: UChPEDGIZ

Vassilyeva, I., \&Andreyev, A., \&Korysheva, S., \&Kuznetsov, M., \&Luzgin, S., \&Kholopova, E. (2019). Pedagogical problems of correcting juvenile delinquents serving a sentence without imprisonment and the ways of their solution. Society. Integration. Education Proceedings of the International Scientific Conference (SIE2019), Volume 1, Higher Education, Rezekne, Latvia, 583-594.

Vygotskij, L. (2010). Pedagogicheskaja psihologija. Moskva: AST, Astrel'. 